\title{
Analysis of Teenagers' Facebook Profile Creation with a Special Focus on Photography: Insights from Croatia
}

\author{
KOME - An International Journal of Pure \\ Communication Inquiry \\ Volume 8 Issue 1, p. 58-79. \\ (C) The Author(s) 2019 \\ Reprints and Permission: \\ kome@komejournal.com \\ Published by the Hungarian Communication \\ Studies Association \\ DOI: $\underline{10.17646 / \text { KOME.75672.35 }}$
}

\author{
Maja Homen Pavlin ${ }^{1}$, Mario Dumančić ${ }^{1}$ and Mirko Sužnjević \\ ${ }^{1}$ Faculty of Teacher Education, University of Zagreb, CROATIA \\ ${ }^{2}$ Faculty of Electrical Engineering and Computing, University of Zagreb, CROATIA
}

\begin{abstract}
Today, phones with integrated cameras and affordable photo equipment make it possible for teenagers to take photos at any time and place. To portray themselves in a certain way, teenagers post photos on social networks such as Facebook and Instagram. The social and technical affordances of Facebook enable identity construction by providing the tools to shape the information and photos posted on an individual's profile in an attempt to regulate how others perceive them. This paper analyzes Facebook profile creation among teenagers with a special focus on photography. The research is based on data obtained through questionnaires taken by 200 12-14-year olds attending primary education schools in Croatia. Research results indicate that teenagers create their profiles on Facebook with great consideration of other people's opinions, but even more for expression of their true selves. For the participants in this study, posting photos that reflect their identity, their feelings, or their lifestyle is more important than posting photos with the intention of being liked by others.
\end{abstract}

Keywords: Facebook, identity, impression management, photography, self-image, social networks

\section{Introduction}

New technologies such as smartphones, tablets, photo cameras, and other similar devices allow people to access the internet, thus enabling them to communicate with each other and share their photos wherever they are and whenever they want to. These new multifunctional communication tools have become an important part of people's daily lives. In recent years, many teenagers, as well as adults, started joining social networking service (SNS) websites. On SNS, individuals have the ability to project and express who they are and construct their online identities to guarantee their appeal to their desired audiences. By creating online identities, individuals can thrive socially because they can present themselves in any way they want. This representation is usually positive, as wanting to be perceived in a positive light is fundamental to human nature. 